УДК 338.24

\author{
Андрієнко Микола, \\ док. наук держ. упр, доцент, \\ E-mail: m.andrienko@idundcz.dsns.gov.ua, \\ ORCID iD: 0000-0002-9222-4831
}

Гаман Петро, док. наук держ. упр., професор, E-mail: gaman@idundcz.dsns.gov.ua, ORCID iD: 0000-0002-3239-8936

\title{
ПРОБЛЕМИ ТА ПЕРСПЕКТИВИ ДЕРЖАВНОГО УПРАВЛІННЯ УКРАЇНИ В УМОВАХ ГЛОБАЛІЗАЦЇ̈ ЕКОНОМІКИ
}

\section{https://doi.org/10.32689/2618-0065-2021-1(7)-6-25}

Анотація. Ефективність відповіді системи державного управління на соціально-економічні, політичні та гуманітарні виклики нової глобалізації та четвертої промислової революції буде залежати від ії здатності забезпечити адекватну мінливій кон'юнктурі ринку праці систему підготовки фахівців, політику зайнятості з високим горизонтом планування, диференціацію по галузях і кластерах виробництва, а також стратегію інноваційного розвитку, що має мінімізувати транзакційні витрати. Глобалізація означає перехід системи національного господарства в інтегроване світове господарство. Вона призводить не просто до встановлення і розвитку відносин між економічними, соціальними та іншими суб'єктами різних країн, а й до різкого збільшення значущості цих відносин. Водночас, вплив глобалізаційних процесів зумовлює необхідність нових теоретичних підходів для обгрунтування структурних зрушень в українській економіці. Розкриті питання спрямовані на формування стійкості до негативних чинників, посилення конкурентоспроможності, реалізація завдань щодо сталого розвитку, забезпечення відповідності встановленим світовим нормам, реагування на загрози посилили актуальність iз точки зору гарантування економічної безпеки України в умовах глобалізаційних викликів. Метою дослідження $є$ виокремлення негативних факторів здійснення глобалізаційних процесів в Україні, аналіз індексу глобалізації, надання пропозицій щодо формулювання заходів стимулювання розвитку цифровізації в Україні. Враховуючи зазначене, в ході дослідження розглянуто основні підходи науковців до поняття «глобалізація»; визначено основні фактори, які заважають здійснювати процеси глобалізації в Україні; виокремлено проблеми формування інформаційного суспільства в Україні; охарактеризовано індекс глобалізації та місце України в ньому; 


\section{Науковий вісник : Державне управління №1 (7) 2021}

проаналізовано цифровізацію в контексті глобалізаційних процесів та сформульовані основні заходи щодо стимулювання цифровізації в Україні.

Ключові слова: державне управління, глобалізація, індекс глобалізації, глобалізаційні процеси, інформаційне суспільство, цифровізація.

Постановка проблеми. Глобалізаційні процеси проникають у внутрішньо-державну сферу через економічні, інформаційні, міжнародно-правові та інші канали. Держава вимушена брати на себе не властиві ій раніше функції (інформаційна безпека, інноваційна діяльність), а також модернізувати попередні, притаманні їй, функції. Крім того, глобалізація в іiі сучасному варіанті приводить до «переформатування» структури сучасного світу, а в результаті цього - до коригування національних систем державного управління, зміни стратегій економічного, політичного та духовного розвитку, що породжує суцільну взаємозалежність світу, яка i складає основу його функціонування. Зростаюча взаємозалежність уніфікує й стандартизує умови та фактори розвитку окремих країн світу, $\epsilon$ своєрідним індикатором визначення рівня сталості розвитку національних держав, а отже, i ïx потенціалу в протистоянні викликам глобалізаційних процесів, які й стають сьогодні основним критерієм об'єднання держав у відповідні глобальні чи регіональні структури. Протистояти таким глобалізаційним викликам здатна лише та держава, яка має активну систему управління, реалізує власну геополітичну стратегію розвитку, максимально оберігає свій суверенітет, орієнтується в глобальному просторі, а головне володіє ефективними механізмами впливу та навіть і управління ним.

Крім того, процеси глобалізації висувають нові вимоги до системи функціонування національних систем державного управління, які мають стати дієвим та ефективним засобом у вирішенні складних міжкультурних суперечностей, особливо тих, які виникають у процесі гармонізації механізмів спільного функціонування національних держав у світовому просторі, а отже, й узгодження відносин між державами та налагодження ефективних форм взаємодії, що певною мірою може сприяти 


\section{Науковий вісник : Державне управління №1 (7) 2021}

забезпеченню відкритості та прозорості сфери міжнародних відносин. У зв'язку із зазначеним, наразі актуальним стає питання виявлення проблем та перспектив державного управління України в умовах глобалізації економіки.

Аналіз останніх досліджень і публікацій. Дослідженню проблемних питань щодо державного управління України в умовах глобалізації присвячено низку наукових праць вітчизняних та зарубіжних дослідників.

На думку О. Білоруса під визначення сутності економічної глобалізації як виходу або, точніше, свідоме винесення економічних інтересів національних господарських суб'єктів за національно-державні рамки, переконує нас у тому, що економічна глобалізація та економічний глобалізм є специфічною формою економічного імперіалізму провідних країн глобалізаторів [1].

В. Воротін зазначає, що поряд 3 внутрішніми факторами (становлення ринкового механізму) на економічну роль держави впливає глобалізація економіки світу та притаманна ій економічна інтеграція, яка досягла особливо високого розвитку в Європі. Ці надзвичайно важливі процеси вимагають від держави вжиття численних заходів: від подолання відставання нашої економіки від європейських країн, наближення способу життя нашого народу до європейських стандартів до приведення законодавства нашої країни у відповідність з європейським [2].

В. Кравченко у своїх працях дійшла висновку, що Україна, як сучасна держава світу, також дуже інтегрована в глобальну економіку, а від так $\epsilon$ дуже чутливою до позитивних та негативних факторів впливу глобалізації на національні економіки. Особливо це помітно в умовах кризових та посткризових явищ, які супроводжують світову економіку останнім часом. Велика залежність України від зовнішніх факторів розвитку, особливо експорту, робить іï економіку дуже вразливою до глобальних економічних потрясінь, які $\epsilon$ невід'ємною частиною сучасної глобалізації [3].

О. Котуков у своїй роботі розглянув питання глобалізації та вважає, що цей процес є беззаперечним чинником суспільного 


\section{Науковий вісник : Державне управління №1 (7) 2021}

розвитку в Україні та світі. Посадовими особами органів публічної служби в Україні вона сприймається як багато вимірний процес, що характеризує сучасний етап розвитку людства, ознаками якого $\epsilon$ : зростання інтеграції; уніфікація практик; збільшення взаємозалежності; формування спільного світового економічного, політичного, культурного простору, правового, ціннісного простору. Основними сферами, на які впливає глобалізація, $\epsilon$ економіка та ринок праці, розвиток інформаційно-комунікативних систем і технологій; сфера суспільних відносин; сфера публічного управління [4].

О. Лозовицький вважає, що глобалізація $\epsilon$ основним процесом, під час якого більша частина соціальної активності здобуває світовий характер, у якому більша частина соціальної активності здобуває світовий характер, у якому географічний фактор втрачає свою важливість або стає незначним у встановлені й підтримці транскордонних економічних, політичних або соціокультурних відносин, що охоплює всі сфери життя сучасного суспільства [5].

Як зазначає В. Зозуля, під час глобалізації відбуваються зміни всіх сфер суспільного життя, обрання державами своїх стратегій подальшого розвитку, виникає потреба в збереженні національних особливостей розвитку, що, у свою чергу, дозволить протистояти глобалізаційним викликам та забезпечити сталий розвиток держави. У контексті глобалізаційних процесів зростає роль демократичного врядування, спостерігається їх взаємозв'язок [6].

Відомий дослідник М. Кастельс описує глобалізацію як «...постійний процес розвитку капіталістичного способу виробництва, який, долаючи межі часу й простору, наприкінці XX століття перетворює світову економіку в глобальну, з новою інфраструктурою, створюваною інформаційними й комунікаційними технологіями» [7]. «Глобальна економіка, - за В. Кастельсом, - це економіка, здатна працювати як єдина система у режимі реального часу в масштабі всієї планети, тому глобалізація пов'язана 3 інформаційною трансформацією суспільства, а не масштабами або економічною діяльністю» [7]. 
На думку експертів Міжнародного валютного фонду (МВФ), глобалізація визначається як зростаючий ступінь інтеграції країн у всьому світі, вона обумовлена, насамперед, торговельними й фінансовими потоками, а також рухом робочої сили й технологій через міжнародні кордони [8].

У 2000 р. відомий дослідник глобалізації Ян Шолте узагальнив трактування глобалізації та виокремив п'ять найбільш ключових іiі визначень [9]. По-перше, глобалізацію слід розглядати як інтернаціоналізацію, що знаходить прояв у поглибленні міжнаціональних соціальних та економічних відносин і поступовому переході до такого типу суспільних відносин, де першочерговими постають глобальні інтереси. Подруге, глобалізація як лібералізація. По-третє, глобалізація як процес, що уніфікує суспільні економічні відносини шляхом поширення знань та досвіду через світові інформаційні системи. По-четверте, глобалізація як процес модернізації суспільства шляхом локального самовизначення та поширення модернізму. По-п'яте, глобалізація як механізм створення єдиного суспільного простору, що немає територіальних обмежень та визначеності. Вона є процесом, що трансформує реконфігурацію географії таким чином, що суспільний простір вже не відображається у поняттях територіальних просторів, територіальних відстаней і кордонів [10].

Таким чином, незважаючи на певну розробленість глобалізаційної проблематики в контексті різних дослідницьких підходів, представлену значною кількістю теоретикометодологічних та практико-прикладних досліджень, і досі поза увагою вчених лишаються актуальні аспекти впливу глобалізації на систему державного управління.

Методи дослідження. В ході дослідження використані такі методи дослідження, як: методи індукції та дедукції - під час дослідження поняття «глобалізація»; спостереження й узагальнення - для встановлення місця державного управління України в умовах глобалізації; упорядкування - при визначенні місця України за індексом глобалізації; графічні методи - при систематизації негативних факторів при здійсненні 


\section{Науковий вісник : Державне управління №1 (7) 2021}

глобалізаційних процесів; методи системно-структурного аналізу - для надання пропозицій щодо заходів стимулювання розвитку цифровізації в Україні; метод наукового узагальнення, що вможливив формулювання висновків.

Постановка завдання. Метою дослідження $є$ виокремлення негативних факторів, що заважають розвитку глобалізаційних процесів в Україні, аналіз індексу глобалізації, надання пропозицій щодо формулювання заходів стимулювання розвитку цифровізації як фактору прискорення глобалізаційних процесів в Україні.

Виклад основного матеріалу дослідження. Головною причиною соціально-економічного падіння вважають кризу не самої економіки, а системи державного управління, наслідком якої є негаразди у всіх сферах життєдіяльності країни. Кризові явища формуються через втрату моралі бюрократичною верхівкою, деградацію гуманістичних цінностей, різноплановість цілей різних соціальних груп населення, тотальну бідність тощо. Низька ефективність управління пояснюється ще й недосконалістю, а часом і відсутністю механізмів державного управління та інструментів їх реалізації.

Глобалізація заявила про себе в 90-х рр. минулого століття як складний i багатогранний процес, який має безліч найрізноманітніших проявів та містить ще більший спектр проблем. У спробі все-таки якось упорядкувати її сутнісні прояви в реальному житті науковці пов'язують глобальні трансформації 3 існуванням світового ринку, глобальними комунікаціями (інформаційною інфраструктурою) та глобальною масовою культурою.

Крім того, глобалізаційний вплив $€$ зовнішнім чинником подій, рішень та наслідків, які виникають за межами відповідної країни, що призводить до внутрішніх змін у певній державі та породжує зворотні реакції відповідей та реагувань. Разом 3 тим, Україна не увійшла в глобальний процес не тому, що не хотіла, а тому що не готова за рівнем міжнародної конкурентоспроможності, за рівнем ефективності державного менеджменту. На противагу попереднім етапам розвитку, що 


\section{Науковий вісник : Державне управління №1 (7) 2021}

характеризувалися порівняно високим ступенем незалежності національних економік і великою свободою рішень, у новій глобалізованій міжнародній економіці залишається дедалі менше можливостей для національних автономій. Глобалізація економіки призводить до практичної неспроможності регулювати ринок та систему виробництва в державі на національному рівні [11].

Доцільно розглянути підходи до поняття «глобалізація», адже вони значно різняться, 3 огляду на складність та масштабність сутності явища та спричинених ним змін, багаторівневість процесів та несформованість повноти зв'язків між суб’єктами глобалізаційної діяльності. Дослідники акцентують на процесах, масштабах впливу, факторах, наслідках та інших особливостях зазначеної дефініції.

На думку Р. Войтович глобалізація визначається як універсальні форми історичної динаміки перехідних суспільств, що дало змогу розкрити основні фактори (вплив ТНК, форми глобальної інтеграції, соціальні та культурні зразки поведінки тощо), типи відносин між суспільствами (єднання і розкол), відповідно до чого ідентифіковано форми синхронізації історичної динаміки перехідних суспільств (глобальна об'єктивна реальність, єдиний соціальний простір, єдині форми соціальної поведінки, глобальна ментальність), рівні (інтеграційна відкритість, дезінтеграційна закритість) та механізми (глобалізаційна взаємостимуляція та глобальна інверсія) функціонування перехідних суспільств [12].

Ю. Ковбасюк розглядає глобалізацію як внутрішньо суперечливий процес, оскільки, з одного боку, вона відкриває нові можливості для політичного та державно-управлінського дискурсу, а з другого - загострює існуючі або породжує нові проблеми, які досить часто виникали на попередніх етапах світового розвитку і остаточно не розв'язані у світовій державноуправлінські практиці [13].

Як зазначала В. Зозуля глобалізація визначається як багатофакторний процес, що має вплив на сфери суспільного життя та на систему державного управління, пропагуючи єдині 


\section{Науковий вісник : Державне управління №1 (7) 2021}

цінності, напрями діяльності на основі демократичного врядування [6].

О. Котуков зазначає, що глобалізація збільшує залежність значної кількості країн від світової економічної кон'юнктури, посилюючи вплив міжнародних інститутів на внутрішню політику незалежних країн. 3 огляду на зазначене, необхідні управлінські дії та контроль багатоаспектних впливів глобалізації на економічну, соціальну, політичну та інформаційні сфери [14].

В Енциклопедії державного управління зазначається, що глобалізація поглиблює та розширює політичний процес у напрямі взаємодії місцевих, національних, регіональних, міжнародних і глобальних подій у комплексі процесів [15].

До основних факторів, які заважають сьогодні здійснювати процеси глобалізації в Україні, належать (рис. 1):

Негативні фактори глобалізаційних процесів в Україні:

- технологічне відставання;

• слабка мобілізаційна активність соціальних прошарків;

• повальна залежність від могутніших держав;

- поглиблення розриву між елітою та масами;

• відсутність громадського контролю;

•корупція державного апарату;

- безальтертнативність стратегічного розвитку;

• утримання від професійної мобілізації;

- досить часте домінування приватних інтересів над публічними;

- тісне переплетення власності та влади;

•нездатність досягнення компромісу та згоди в політичній сфері;

- трансформація політичної партії;

- механізми артикуляції та агрегації інтересів у контексті досягнення приватних інтересів як способу отримання влади.

Рисунок 1 - Негативні фактори глобалізаційних процесів в Україні Джерело: систематизовано авторами на основі [16] 


\section{Науковий вісник : Державне управління №1 (7) 2021}

Українська система державного управління потребує глибокої модернізації всіх сфер суспільної життєдіяльності та вміння використовувати у своїх національних інтересах тих ресурсів, які відкриваються у процесі взаємодії між державами в умовах глобалізації, яка врешті-решт зближує між собою держави за окремими параметрами. Проте в українській дійсності такий підхід здебільшого викликає ризики, а не приводить до оптимізації системи державного управління.

Передусім це пов'язується 3 високим рівнем відкритості України до світових інтеграційних процесів. Це, у свою чергу, підтверджується «Рейтингом глобалізації», опублікованим журналом Foreign Policy.

Індекс глобалізації (KOF Globalisation Index) вимірює економічні, соціальні та політичні аспекти глобалізації. Індекс глобалізації KOF має на меті виміряти темпи глобалізації в країнах світу. Індекс базується на трьох вимірах або основних наборах показників: економічному, соціальному та політичному. За допомогою цих трьох вимірів загальний індекс глобалізації намагається оцінити поточні економічні потоки, економічні обмеження, дані про інформаційні потоки, дані про особистий контакт та дані про культурну близькість в межах опитуваних країн.

Глобалізація визначається як процес створення мереж зв'язків між суб'єктами на багатоконтинентальних відстанях, опосередкованих за допомогою різних потоків, включаючи людей, інформацію та ідеї, капітал та товари. Це процес, який розмиває національні кордони, інтегрує національні економіки, культури, технології та управління та створює складні відносини взаємної взаємозалежності [17].

Статистика показує 50 кращих країн за індексом глобалізації в 2020 році. У 2020 році Швейцарія була найбільш глобалізованою країною світу, за нею йдуть Нідерланди та Бельгія. На наступні місця вийшли Швеція, Великобританія, Данія, Німеччина, Франція, Фінляндія та Норвегія. Перші неєвропейські країни - Канада на 16-му місці, Сінгапур - на 20- 
му та США - на 23-му місці. Аутсайдери рейтингу - Уругвай, Ісландія, Катар [16-17].

Через більшу ступінь взаємозалежності, наприклад, із сусідніми країнами, менші країни, як правило, вищі в цьому рейтингу, ніж великі. Це залишає найбільші національні економіки у всьому світі середнього діапазону. США посіли 65-те місце в економічній глобалізації, 23-е та 12-те місце в соціальній та політичній глобалізації. Китайська Народна Республіка займає 79 місце в загальному індексі. Хоча вона посідає 27 місце за політичною глобалізацією, іï ступінь економічної та соціальної глобалізації значно нижчий. Третя за величиною економіка світу, Японія, займає 36-е місце. Великі економіки $\mathrm{CC}$, такі як Німеччина, Великобританія, Франція та Іспанія, загалом набагато більш глобалізовані через високий рівень економічної, соціальної та політичної взаємозалежності всередині СС. У загальному рейтингу Великобританія посідає 5 місце, Франція - 8-е, Україна - 42 місце [17].

Слід відзначити, що за два останні роки рейтинг найбільш глобалізованих держав у світі практично не змінився. Десятку лідерів глобалізаційного розвитку очолюють США, Нідерланди, Канада, Данія, Швеція, Австрія, Фінляндія, останні ж місця у рейтингові займають Іран, Індія, Індонезія, Сгипет і Бангладеш [16].

У сучасному глобалізованому світі бурхливо змінюється характер взаємовідносин громадян 3 органами влади, модернізуються процедури управлінських дій, з'являються нові засоби глобального зв'язку. Все це в сукупності приводить до виникнення нових тенденцій функціонування вітчизняної системи державного управління.

Важливою проблемою для кожної постіндустріальної держави є визнання єдиної альтернативи суспільного розвитку, яка базується на принципі глобалізму. Це являє собою максимальний ризик для розвитку національної системи державного управління, оскільки виноситься питання про національну самобутність та ментальну регламентованість системи організації державної влади. Важливою проблемою 
постає визначення конкретної ролі держави, яка має здійснювати всеохоплюючий контроль за глобальним розвитком світу.

Характерною особливістю системи державного управління України є нездатність дати адекватну відповідь міжнародному співтовариству на традиційні глобальні проблеми забруднення довкілля, потепління клімату, скорочення площ лісів, рибних запасів тощо, які мають тенденцію до поглиблення [18].

Важливою проблемою сьогодні для України $\epsilon$ також чітке визначення ролі транснаціональних корпорацій, наскільки вони здатні прискорити соціально-економічний розвиток держави. Передусім йдеться про пошук механізмів, які б забезпечили через діяльність транснаціональних корпорацій зростання в середині Української держави. Передусім йдеться про створення механізмів стимулювання зовнішніх інвестицій та поєднання їх із внутрішніми, аби таким чином забезпечити ефективний розвиток держави в умовах глобалізації. У цьому плані доцільно виробити чіткі пріоритети суспільного розвитку, а виходячи із цього визначити ті галузі чи сфери, які найбільшою мірою потребують зовнішніх інвестицій. Головним чином потрібно враховувати ті сфери, які мають найбільш потужний потенціал i можуть забезпечити зростання України.

Виходячи з цього, Україна має дбати про те, як використати діяльність транснаціональних корпорацій (зокрема, що стосується іноземного капіталу) таким чином, аби ті сприяли виключно реалізації національних інтересів. Слід відзначити, якщо держава $є$ високорозвиненою за багатьма параметрами (економічним, політичним), то ій значно простіше спрямувати діяльність транснаціональний корпорацій на свою користь, інакше діяльність таких структур може породжувати лише ризики. Одним із ризиків діяльності транснаціональних структур може бути і той факт, що вони досить часто у державах, які відстають у своєму суспільно-політичному та економічному розвитку, можуть впроваджувати застарілі технології.

Також діяльність транснаціональних корпорацій може приводити до монополізації окремих галузей розвитку в межах тієї чи іншої держави, а це, безумовно, є одним із ризиків 


\section{Науковий вісник : Державне управління №1 (7) 2021}

національної безпеки. Слід також відзначити, що здебільшого діяльність транснаціональних структур супроводжується створенням нових соціальних стандартів, а це, у свою чергу, порушує усталену логіку діяльності національних структур, в результаті чого останні просто вимушені дотримуватись нових корпоративних правил [19].

Саме тому аби забезпечити собі конкурентність у світі, Україна має створювати власні транснаціональні структури, власні бренди, навіть якщо у нас не вистачає власних ресурсів, їх можна експортувати. Яскравим прикладом у цьому плані може слугувати шведський концерн «Вольво», який майже $80 \%$ комплектуючих ввозить із-за кордону, проте йому вдається створювати технологічно конкуренту продукцію у світі, яка сьогодні певною мірою визначає і бренд країни в цілому.

Розвиток глобалізаційних процесів прискорюється в інформаційному суспільстві, на етап формування якого перейшла вся світова спільнота. Тому цифрофізація суспільних відносин сприятливий фактор прискорення розвитку глобалізацій них процесів в Україні.

Цифровізація - насичення фізичного світу електронноцифровими пристроями, засобами, системами та налагодження електронно-комунікаційного обміну між ними, що фактично уможливлює інтегральну взаємодію віртуального та фізичного, тобто створює кіберфізичний простір [20]

Основна мета цифровізації полягає у досягненні цифрової трансформації існуючих та створенні нових галузей економіки, а також трансформації сфер життєдіяльності у нові більш ефективні та сучасні. Такий приріст є можливим лише тоді, коли ідеї, дії, ініціативи та програми, які стосуються цифровізації, будуть інтегровані, зокрема, в національні, регіональні, галузеві стратегії i програми розвитку. Цифровізація $\epsilon$ визнаним механізмом економічного зростання завдяки здатності технологій позитивно впливати на ефективність, результативність, вартість та якість економічної, громадської та особистої діяльності.

Робота над цифровізацією розпочалась ще у січні 2018 року iз затвердження Концепції розвитку цифрової економіки та 
суспільства України на 2018-2020 роки та плану заходів щодо іï впровадження. Мета даної Концепції - заохотити бізнес та громадян до споживання та використання інформаційнокомунікаційних технологій як більш ефективних, якісних, дешевших та швидших [20].

Цифровізація безсумнівно має велику кількість переваг для суспільства, підприємництва та держави. Зокрема, вона здатна знизити відсоток тіньової економіки та корупції в країні, адже транзакції, що здійснюються цифровим шляхом, можна легко контролювати. Крім того, поява внутрішнього ринку цифрових технологій створить нові можливості для українських ITкомпаній, що зупинить відтік висококваліфікованих кадрів за кордон. 3 іншого боку, існують загрози безпеці даних у вигляді кібератак. Нові технології, особливо штучний інтелект, призведуть до серйозних зрушень на ринку праці, включно зі зникненням робочих місць в одних секторах та їх появою в інших. Україна повинна бути готова до таких кардинальних змін [21].

Основні заходи щодо стимулювання розвитку цифровізації в Україні перераховані на рис. 2.

Таким чином, на даному етапі розвитку суспільства ми вже маємо можливість оцінити переваги й можливості, що подарували людству інноваційні технології, та констатувати, що й надалі без активного застосування новітніх досягнень інформатики, радіоелектроніки, зв'язку, обчислювальної й телекомунікаційної техніки ефективно керувати державою, іiі економікою буде неможливо. Тому розвиток інформаційного суспільства в Україні та впровадження його в усі сфери суспільного життя, зокрема у діяльність органів державної влади та органів місцевого самоврядування, є одним 3 пріоритетних напрямів державної політики.

Для покращення механізмів публічного управління та адміністрування у сфері цифрових трансформацій необхідно розробляти на державному рівні загальнонаціональні програми, які були б направленні на підтримку та розвиток інфраструктури українського суспільства в цілому. Для цього, з боку держави, 
необхідна підтримка стимулювання та розвитку цифрових технологій, зокрема, системи культивування цифрових навичок

\section{Заходи щодо стимулювання розвитку} цифровізації в Україні:

• розбудова фіксованої інфраструктури широкосмугового Інтернету;

• розбудова інфраструктури мобільного Інтернету (4G, 5G);

- створення нових технологій кібербезпеки;

• створення технічної бази для е-комерції та е-бізнесу;

• розвиток блокчейн-технлогій, зокрема в фінансовий та банківських сферах;

- створення бази відкритих даних;

• створення інфраструктури для транзакційно-процесингових операцій;

- оціфрування усіх фізичних структур транспортної, енергетивної, житлово-комунальної та інших галузей економіки.

Рисунок 2 - Заходи щодо стимулювання розвитку цифровізації в Україні Джерело: сформовано авторами

на рівні початкової, середньої та вищої освіти. Важливо для цього розглянути можливість що отримання освіти для літніх людей, які зможуть отримати додаткову освіту (знання), які б відповідали їхнім потребам та інтересам, користування новими можливостями цифрових технологій. Адже, цифрові технології, стали базою для створення нових продуктів, цінностей, властивостей та, відповідно, основою отримання конкурентних переваг на більшості ринків. На сьогодні відбувається «цифровий перехід» від свого роду «аналогових» систем та процесів індустріальної економіки та інформаційного суспільства до «цифрової» економіки та «цифрового» суспільства. Така трансформація приводить до появи нових, унікальних систем i 


\section{Науковий вісник : Державне управління №1 (7) 2021}

процесів, що складають їх нову ціннісну сутність, адже до цифрових трансформацій схильні більшість звичних для громадян видів діяльності

Висновки та перспективи подальших досліджень. Таким чином, глобалізація $є$ невід'ємною частиною життєдіяльності кожної сучасної держави у світі. Глобалізація в подальшому буде набирати ще більше обертів і тому кожній державі потрібно шукати можливості для використання переваг та вирішення проблем, які виникають у наслідок глобалізації світової економіки та суспільного життя.

У результаті проведеного дослідження було проаналізовано основні проблеми розвитку економіки України в умовах глобальних трансформаційних процесів, пов'язаних 3 цифровізацією. Для України цифровізація може стати поштовхом до модернізації економіки та подолання кризи. Аналіз теперішнього стану іiі розвитку свідчить про те, що подальше впровадження цифрових технологій в усі сектори економіки неможливе без усунення наявних на їх шляху перешкод: недостатній захист прав інтелектуальної власності, високі інвестиційні ризики, низький рівень кібербезпеки та наявність піратства. Серед інших проблем - недостатня мотивація для цифровізації суспільства. Політика держави має бути націлена на те, щоб забезпечити умови щодо впровадження і використання нових цифрових засобів, замість традиційних, серед громадян та у сфері бізнесу, зробити цифрові технології доступними для споживачів, тим самим збільшивши попит на них. Лише в такому випадку можна ефективно оптимізувати вигоди цифрової економіки, мінімізуючи при цьому іiі ризики. Крім того, варто констатувати, механізми публічного управління та адміністрування у сфері цифровізації повинно системно удосконалюватися, оскільки цифровізація повинна стати головним інструментом для досягнення стратегічної цілі України - економічне зростання держави, забезпечить добробут, комфорт та якість життя населення України на рівні країн Свропи.

Подальші наукові дослідження у цій сфері можуть бути присвячені аналізу держав-лідерів у сфері цифровізації 


\section{Науковий вісник : Державне управління №1 (7) 2021}

публічного врядування з метою прискорення переходу України на новий інноваційний рівень суспільно-владних відносин повсюдного цифрового врядування.

\section{Список використаних джерел}

1. Білорус О. Г. Історичні та стратегічні імперативи трансформації та модернізації транзитивних країн в умовах глобалізації. Історичні та стратегічні імперативи модернізачії провідних $i$ транзитивних країн світу. 2017. С. 5 - 12.

2. Воротін В. Є. Формування системи державного регулювання національної економіки в умовах глобальних ринкових трансформацій : автореф. дис. д-ра наук з державного управління : 25.00.02. Київ, 2003. 29 с.

3. Кравченко В. О., Гудаков О. К. Соціально-економічні наслідки глобалізації для світової та української економіки. Теоретичні $i$ практичні аспекти економіки та інтелектуальної власності. 2013. Вип. 2. Т. 1. С. $70-75$.

4. Котуков О. Особливості впливу глобалізації на сучасні суспільні відносини і публічну службу в Україні. Ефективність державного управління. 2018. Вип. 2 (55). Ч. 1. С. $169-177$.

5. Лозовицький О. С. Глобалізація і держава: світовий інтеграційний процес чи регіональний перерозподіл? Наукові записки Інституту політичних етноначіональних досліджень імені І. Ф. Кураса. 2011. Вип. 6. С. $124-134$.

6. Зозуля В. Вплив глобалізації на демократичне врядування: теоретико-методологічні підходи. Public Administration. 2017. № 2(33). С. $14-18$.

7. Кастельс М. Інформаційні технологіi, глобалізація та соціальний розвиток. Соціальна глобалістика : навч. посіб. / за наук. ред.: Е. А. Афоніна, В. Д. Бондаренка, А. Ю. Мартинова. Київ : Освіта України, 2011. 1електрон.опт.диск (CD ROM); 12 см.

8. Потенциал и опасности глобализации. Тематический обзор МВФ от 12.04.2000. URL : https://cutt.ly/hkmICzq (дата звернення 08.02.2021).

9. Scholte J. A. Globalization. A critical introduction. London: Palgrave, 2000. $361 \mathrm{p}$.

10. Стігліц Дж. Глобалізація та її тягар / пер. 3 англ. А. Іщенко. Київ : Вид. дім "КМ Академія", 2003. 252 с.

11. Решетило В. П., Островський І. А. Глобальні виклики структурної модернізації економіки України. Глобальні та нащіональні проблеми економіки. 2018. Випуск 23. С. 38 - 43. 


\section{Науковий вісник : Державне управління №1 (7) 2021}

12. Войтович Р. В. Вплив глобалізації на систему державного управління: автореферат дис.. на здобуття наук. ступеня д-ра наук 3 державного управління : 25.00.02. Київ, 2009. 39 с.

13. Ковбасюк Ю. В. Детермінований вплив глобалізації на розвиток сучасних систем державного управління. Вісник національної академї̈ прокуратури Украӥни. 2015. №1. С. 5 - 12.

14. Котуков О. А. Феномен глобалізації та його вплив на сучасне державне управління. Актуальні проблеми державного управління. 2014. № 1. С. $24-34$.

15. Енциклопедія державного управління: у 8 т. / Нац. акад. держ. упр. при Президентові України ; наук.-ред. кол. : Ю. В. Ковбасюк (гол.) та ін. Київ : НАДУ, 2011. Т. 7 : Державне управління в умовах глобальної та європейської інтеграції / наук.-ред. колегія : I. А. Грицяк (співголова), Ю. П. Сурмін (співгол.) та ін. 764 с. URL : http://academy.gov.ua/NMKD/library nadu/Encycloped vydanniy/ec33d 206-7309-4034-a00f-074bcb7916ce.pdf (Дата звернення 11.01.2021).

16. KOF Globalisation Index: Globalisation Lull Continues. Eidgenössische Technische Hochschule Zürich. URL: https://kof.ethz.ch/en/news-andevents/media/press-releases/2018/12/kof-globalisation-indexglobalisation-lull-continues.html (Дата звернення 12.01.2021).

17. KOF Globalization Index - 100 most globalized countries 2020 // Statista. URL: https://www.statista.com/statistics/268168/globalizationindex-by-country/ (Дата звернення 12.01.2021).

18. The official site of KOF Index of Globalization. URL : https://www.hse.ru/org/hse/4432173/mathbase/databases/db 35 (Дата звернення 12.01.2021).

19. Perspectivo in Developemento, Springo 2004. Pace Bank. Washington. Roma, $187 \mathrm{p}$.

16. Офіційний сайт Українського інституту майбутнього. URL : https://strategy.uifuture.org/kraina-z-rozvinutoyu-cifrovoyuekonomikoyu.html (Дата звернення 13.01.2021).

20. Про схвалення Концепції розвитку цифрової економіки та суспільства України на 2018-2020 роки та затвердження плану заходів щодо іiі реалізації : розпорядження Кабінету Міністрів України від 17 січня 2018 p. № 67-p. URL : https://zakon.rada.gov.ua/laws/show/67-2018-\%D1\%80\#Text (Дата звернення 13.01.2021).

21. Тульчинська С. О., Корзун Л. С. Цифровізація як засіб трансформації економіки України. Сучасні проблеми економіки $i$ підприємництво. 2020. №25. С. 52 - 59. 


\section{Науковий вісник : Державне управління №1 (7) 2021}

\section{References}

1. Bilorus, O. H. (2017), Istorychni ta stratehichni imperatyvy transformatsii ta modernizatsii tranzytyvnykh krain $\mathrm{v}$ umovakh hlobalizatsii [Historical and strategic imperative transformations and modernization of transit countries in the context of globalization], Istorychni ta stratehichni imperatyvy modernizatsii providnykh $i$ tranzytyvnykh krain svitu, pp. 512 [in Ukrainian].

2. Vorotin, V. Ye. (2003), Formuvannia systemy derzhavnoho rehuliuvannia natsionalnoi ekonomiky $v$ umovakh hlobalnykh rynkovykh transformatsii [Formation of the system of state regulation of the national economy in the conditions of global market transformations], (Extended abstract of doctor's thesis), Kyiv [in Ukrainian].

3. Kravchenko, V. O. and Hudakov, O. K. (2013), Sotsialno-ekonomichni naslidky hlobalizatsii dlia svitovoi ta ukrainskoi ekonomiky [Socioeconomic consequences of globalization for the world and Ukrainian economy], Teoretychni i praktychni aspekty ekonomiky ta intelektualnoi vlasnosti, № 2, part 1, pp. 70-75 [in Ukrainian].

4. Kotukov, O. (2018), Osoblyvosti vplyvu hlobalizatsii na suchasni suspilni vidnosyny i publichnu sluzhbu $\mathrm{v}$ Ukraini [Features of the impact of globalization on modern social relations and public service in Ukraine], Efektyvnist derzhavnoho upravlinnia, №. 2 (55), part 1, pp. 169-177 [in Ukrainian].

5. Lozovytskyi, O. S. (2011), Hlobalizatsiia i derzhava: svitovyi intehratsiinyi protses chy rehionalnyi pererozpodil? [Globalization and the state: global integration process or regional redistribution?], Naukovi zapysky Instytutu politychnykh etnonatsionalnykh doslidzhen imeni I. F. Kurasa, №6, pp. 124-134 [in Ukrainian].

6. Zozulia, V. (2017), Vplyv hlobalizatsii na demokratychne vriaduvannia: teoretyko-metodolohichni pidkhody [The impact of globalization on democratic governance: theoretical and methodological approaches], Public Administration, № 2(33), pp. 14 - 18 [in Ukrainian].

7. Kastel's, M. (2011), Informatsiyni tekhnolohii, hlobalizatsiya ta sotsial'nyy rozvytok [Information technology, globalization and social development], Osvita Ukrayiny, Kyiv, Ukraine[in Ukrainian].

8. The potential and the dangers of globalization. IMF Issues Brief on 12.04.2000, retrieved from : http://www.imf.org/ external/np/exr/ib/2000/rus/041200r.htm [in Russian].

9. Scholte, J. A. (2000), Globalization. A critical introduction. London: Palgrave, 361 p. [in English].

10. Stiglits, Dzh. (2003), Hlobalizatsiya ta yiyi tyahar [Globalization and its load], Vyd. dim "KM Akademiya", Kyiv, Ukraine, p. 252 [in Ukrainian].

11. Reshetylo, V. P. and Ostrovskyi, I. A. (2018), Hlobalni vyklyky strukturnoi modernizatsii ekonomiky Ukrainy [Global challenges of 
structural modernization of Ukraine's economy], Hlobalni ta natsionalni problemy ekonomiky, №23, pp. 38 - 43 [in Ukrainian].

12. Voitovych, R. V. (2009), Vplyv hlobalizatsii na systemu derzhavnoho upravlinnia [The impact of globalization on the system of public administration], (Extended abstract of doctor's thesis), Kyiv [in Ukrainian].

13. Kovbasiuk, Yu. V. (2015), Determinovanyi vplyv hlobalizatsii na rozvytok suchasnykh system derzhavnoho upravlinnia [Determined influence of globalization on the development of modern public administration systems], Visnyk Natsionalnoi akademii derzh. Upravlinnia pry Prezydentovi Ukrainy, № 1, pp. 5-12 [in Ukrainian].

14. Kotukov, O. A. (2014), Fenomen hlobalizatsii ta yoho vplyv na suchasne derzhavne upravlinnia [The phenomenon of globalization and its impact on modern public administration], Aktualni problemy derzhavnoho upravlinnia, № 1, pp. 24-34 [in Ukrainian].

15. Kovbasiuk, Yu. V. (2011), Encyclopedia of Public Administration [Encyclopedia of Public Administration], Kyiv : NADU. Retrieved from : http://academy.gov.ua/NMKD/library_nadu/Encycloped_vydanniy/ec33d 206-7309-4034-a00f-074bcb7916ce.pdf [in Ukrainian].

16. KOF Globalisation Index: Globalisation Lull Continues. Eidgenössische Technische Hochschule Zürich. Retrieved from : https://kof.ethz.ch/en/news-and-events/media/press-releases/2018/12/kofglobalisation-index-globalisation-lull-continues.html [in English].

17. KOF Globalization Index - 100 most globalized countries 2020 // Statista. Retrieved from https://www.statista.com/statistics/268168/globalization-index-bycountry/ [in English].

18. The official site of KOF Index of Globalization. Retrieved from : https://www.hse.ru/org/hse/4432173/mathbase/databases/db_35 [in English].

19. Perspectivo in Developemento, Springo 2004. Pace Bank. Washington. Roma, 2004. 187 p. [in English].

20. Law of Ukraine On approval of the Concept of development of the digital economy and society of Ukraine for 2018-2020 and approval of the action plan for its implementation. Activity from January 17, 2018, № 67-p. Retrieved from : https://zakon.rada.gov.ua/laws/show/67-2018\%D1\%80\#Text [in Ukrainian].

21. Tulchynska, S. O. and Korzun, L. S. (2020), Tsyfrovizatsiia yak zasib transformatsii ekonomiky Ukrainy [Digitalization as a means of transforming Ukraine's economy]. Suchasni problemy ekonomiky $i$ pidpryiemnytstvo, №25, pp. 52-59. [in Ukranian]. 


\title{
PROBLEMS AND PROSPECTS OF PUBLIC ADMINISTRATION IN UKRAINE IN THE CONDITIONS OF GLOBALIZATION
}

\author{
Andriienko Mykola, Haman Petro
}

\begin{abstract}
Clusters., as well as an innovation development strategy that should minimize transaction costs. Globalization means the transition of the national economy to an integrated world economy. It leads not only to the establishment and development of relations between economic, social and other actors of different countries, but also to a sharp increase in the importance of these relations. At the same time, the impact of globalization processes necessitates new theoretical approaches to justify structural changes in the Ukrainian economy. Economic policy in modern Ukraine is also formed under the influence of the existing structure of the national economy. The Ukrainian economy is characterized by a fairly high degree of heterogeneity. Gaps in the level of competitiveness, profitability, wages are determined by the transitional nature of the current model of economic development. At the same time, the processes of globalization and the formation of the information society should help increase the efficiency of public administration, which aims to solve socio-economic problems and improve the quality of life. Issues aimed at building resilience to negative factors, strengthening competitiveness, implementing sustainable development goals, ensuring compliance with established international norms, responding to threats have increased relevance in terms of ensuring Ukraine's economic security in the face of globalization challenges. Given the above, the study considers the main approaches of scientists to the concept of "globalization"; the main factors that hinder the processes of globalization in Ukraine are identified; the problems of formation of information society in Ukraine are singled out; the index of globalization and the place of Ukraine in it are characterized. Based on the obtained scientific results, proposals are made to raise the level of public administration in Ukraine in the context of globalization.
\end{abstract}

Key words: public administration, economic security, globalization, globalization index, globalization processes, information society. 